https://www.edutus.hu/cikk/femalkatreszek-additiv-es-szubtraktiv-modon-torteno-gyartasanakosszehasonlitasa/

\title{
FÉMALKATRÉSZEK ADDITÍV ÉS SZUBTRAKTÍV MÓDON TÖRTÉNŐ GYÁRTÁSÁNAK ÖSSZEHASONLÍTÁSA
}

\author{
SEREGI BÁLINT LEON, egyetemi hallgató \\ Budapesti Müszaki és Gazdaságtudományi Egyetem \\ seregibalint@edu.bme.hu \\ FiCZere PÉTER PhD, egyetemi adjunktus \\ Budapesti Müszaki és Gazdaságtudományi Egyetem \\ ficzere.peter@kjk.bme.hu \\ Borbás Lajos PhD, Professor Emeritus \\ EDUTUS Egyetem \\ borbas.1ajos@edutus.hu
}

\begin{abstract}
ABSZTRAKT
A bemutatott elméleti összehasonlítás célja az additív és szubtraktív módon elöállított fémalkatrészek különböző tulajdonságainak összevetése, mint felületi érdesség, gyárthatóság vagy gyártási idő szempontjából. A vizsgálatot a két gyártási mód jellegzetességéből adódó tulajdonságok felhasználásával végezzük. Az összehasonlítás célja, hogy egy legyártani kívánt alkatrészről el tudjuk dönteni melyik gyártástechnológiával érdemesebb létrehozni, ha az általunk kiválasztott paramétert részesítjük előnyben (gyártási sebesség, felületi minőség).
\end{abstract}

\begin{abstract}
The purpose of this theoretical comparison presented is to compare the different properties of metal parts produced by additive or subtractive manufacturing. Part properties like surface roughness, manufacturability or production time are crucial, but we need to choose one of them as our main preference. The test is performed using the properties resulting from the characteristics of the two production methods. The aim of the investigation is to be able to decide which production technology is better to use for a part to be manufactured if we prefer the parameter we have chosen to be more important (production speed, surface quality).
\end{abstract}

\section{Bevezetés}

Egy előgyártmányból létrehozni a kívánt munkadarabot, hasonló a szobrászathoz. Meg kell tervezni mekkora méretü lesz a teljes alkatrész, milyen anyagból készüljön, milyen minőségü legyen a felülete és mindezt a szerszámok gondos kiválasztásával. Ma már az iparban elterjedt legkorszerübb számítógép vezérelt forgácsolást használják a lehető legnagyobb pontosság és felületi minőség eléréséhez. A vezérlőhöz szükséges programokat is már egy szoftver készíti el. A tervezőknek csak a modellt és a megmunkálási paramétereket kell megadni, de egyes 
esetekben ezt is a számítógép számolja ki. Gyárthatóság szempontjából figyelembe kell venni a darab geometriáját. Vannak olyan geometriák, amelyeket egy háromtengelyes megmunkálással is le tudunk gyártani, de komplex térgörbével rendelkező kontúrok esetén már szükséges az 5 tengelyes forgácsológép használata a darab forgatásával vagy a szerszám döntésével (esetleg mindkettő). Jelenleg az 5 tengelyes megmunkálás jelenti a csúcsot, de ezzel a technológiával sem érhető el bármilyen geometria. A nyomtatás esetén annál inkább, hiszen ezzel a térgörbék mellett üreges darabokat is gyárthatunk. A CNC-s forgácsoló megmunkálással és a 3D fémnyomtatással nem csak sokkal nagyobb rugalmasságot érhetünk el, de akár egy sokkal költséghatékonyabb gyártást is megvalósíthatunk. Ez persze nagyon sok szemponttól függ, mint például az alkatrész geometriája, a gyártandó darabmennyiség és nem utolsó sorban a mechanikai tulajdonságok. Ehhez azonban meg kell érteni a különböző folyamatok előnyeit, hátrányait és mérlegelni, hogy melyik út járható, ha két ilyen alapjaiban teljesen különböző gyártástechnológiát szeretnénk használni közösen.

\section{Módszer}

Az összehasonlításhoz először szükségünk van az egyes technológiák jellemzőire, hogy milyen paraméterekkel tudunk gyártani.

\subsection{Szubtraktív gyártástechnológia}

A forgácsolás olyan anyagmegmunkáló módszer, amelynél a kiinduló darabról a fölösleges részeket - egy arra alkalmas szerszám segítségével - forgács formájában távolítják el. A forgácsolás történhet mértanilag határozott és határozatlan élü szerszámmal. Néhány fogácsolási müveletet kézzel is el lehet végezni, de általában gépi erővel, forgácsológépekkel dolgoznak. Az alapelv, hogy egy kívánt munkadarabnál nagyobb méretü anyagtömbről (előgyártmány) választjuk le a nem kívánt anyagmennyiséget, ezzel a megtervezett darab geometriáját elérve. Mivel a 3D nyomtatást állítjuk szembe a forgácsolással, az összehasonlítás pontosabb lesz összetett (komplex) alkatrészek esetén (1. ábra), ahova már szükséges az 5 vagy $3+2$ tengelyes marás, mivel egy egyszerübb geometriájú darab nyomtatása nem feltétlen lenne hatékonyabb a forgácsolással szemben sem költségben, sem sebességben. Persze ha a fel nem használt anyagmennyiséget nézzük, akkor a 3D nyomtatás elötérbe kerülhet, viszont ehhez a technológiához sokkal drágább az alapanyag és maga a gép is. A legfontosabb kérdés, hogy a szerszám mindenhol oda fér-e a megmunkálandó felülethez. A leggyorsabb gyártási idő eléréséhez érdemes háromtengelyes darabként kezelni a marást és nagyolni, mert az 5 tengelyre 
való áttérés esetén kisebb fogásokat tudunk venni. Ennek az oka, hogy a felületek lekövetésekor már csak a felület simítását végezzük.

1. ábra: példa az összetett (komplex) felületre(zölddel), amit már 5 tengelyes marással érdemesebb kimarni

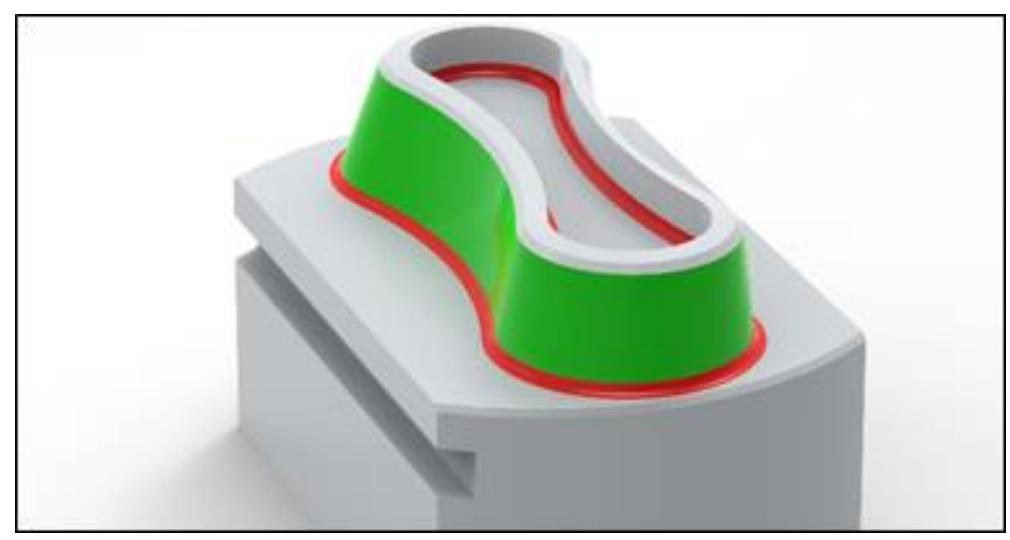

Forrás: saját modell

\subsection{Additív gyártástechnológia}

Az additív megmunkálás egymásra épülő rétegek $(10 \mu \mathrm{m}-100 \mu \mathrm{m})$ létrehozásával hozza létre a kész munkadarabot, ezzel átlépve a hagyományos gyártás korlátait. A felület minősége nagyban függ a rétegek vastagságától, a nyomtatás sebességétöl és a munkadarab orientációjától is. Ugyanakkor figyelni kell a darab geometriájából adódó szükséges támasztékok mennyiségére és elhelyezésére (Ficzere, 2021). A technológián belül a fémnyomtatással való alkatrészgyártást vizsgáljuk. Ahhoz, hogy a virtuális alkatrészünkből egy fizikai kézzel fogható darabot készíthessünk, meg kell tenni néhány lépést. Elöször a 3D-s CAD modellt stl (Standard Triangular Language) formátummá kell alakítani, ami háromszögekkel fedi le a modell felületeit. Íves felületek esetén ezeknek a háromszögeknek a mérete határozza meg a pontosság mértékét, mivel például egy gömb sok kisebb háromszögböl összerakva egy szögletes forma lesz, így a tökéletes gömb formához közelítés feltétele a minél kisebb háromszögek használata. (Gebhardt, 2011) Ezt a méretbeli megközelítést a szakirodalom Cord height-nak hívja. Az stl fájlt egy digitális szeletelő programmal (slicer) a már említett vastagságú rétegekre osztja a darabot (Győri \& Ficzere, 2016). A szeletelés iránya változtatható, ami formától és technológiától is függ. Ebben a programban lehet a darab kitöltésének mintáját és a falvastagságot is beállítani. Nagyon fontos, hogy a darab orientációjából adódóan szükség lehet támasztékra (support), hogy a tartás nélküli peremek kapjanak alátámasztást, mivel ez belső feszültséget és geometriai eltérést is okozhat (Ficzere et al., 2017). Ez kiküszöbölhető, ha a munkadarabot is bedöntjük. Ennek a magyarázata, hogy az építési irány és a gravitációs vektor párhuzamosak. (Prahar és társai, 2019) A fémnyomtatók 
esetében több technológia létezik. A DMLS (Direct Metal Laser Sintering), a munkatérben egy fémporral töltött finom szemcsés ágy helyezkedik el és a legfelső réteget egy program-vezértelt lézerrel megolvasztja a port, aminek köszönhetően összeáll/heged az anyag. A kép, amit a lézer lekövet, a szeletelés során létrejött kép. Tulajdonképpen az alkatrész szelvénye. Miután a lézer végig pásztázta a szelet teljes képét, egy görgővel egy új réteg port fektet a munkatérbe, de elötte süllyeszti a munkaasztalt. Ennek a süllyedésnek a magassága a rétegvastagságnak felel meg. Nagyjából 50 folyamatparamétert vehetünk figyelembe, melyek közül néhány állandó, mások állíthatók (az ágy tulajdonságai, felhasznált anyag, az újra húzott réteg paraméterei stb.) (Michael Kalms, Ralf B. Bergmann, 2020). Mikor a darab kész, a munkaasztal teljesen felemelkedik és a fel nem használt por lesöprése után, ki is vehető a kamrából. Ezzel a technológiával sajnos nem lehet megoldani, hogy egy gépen belül történjen a posztprocesszálás marás vagy hőkezelés formájában. A porágyas technológia egyik problémája, az újonnan lefektetett rétegek durvasága és hullámossága. Ezeket a jellemzőket nagyon nehéz kontrollálni, csak a megfelelő réteghúzó mechanizmussal és folyamatos gyártás közbeni ágy vizsgálattal lehet elérni (lézerrel, kamerával). Ennek vizsgálata nagyon bonyolult, érzékeny és összetett vizsgálatokat igényel. Egyik ilyen megoldás a Structure Function-nak nevezett eljárás, aminek segítségével a kamera képével és több képfeldolgozó zajszürés után az algoritmus meg tudja becsülni az elérhető felületi érdességet, valamint az esetleges hullámosságát. (Kalms és Bergmann, 2020). Egy másik technológia az LDT (Laser Deposition Technology), ahol fémport fújnak fókuszáltan egy fúvóka segítségével egy nagy erejü lézer sugár fókuszpontjába, mindezt egy igen kontrollált atmoszférikus közegben. A fókuszált lézer megolvasztja a finom porszemcséket és egy kis olvadt fém medencét hoz létre az anyagból. Itt szintén rétegesen, új rétegek egymásra fújásával épül fel a darab. Ezt a technológiát egy teljesen új alkatrész gyártásra, de akár javításra is lehet használni. Kiemelendő, hogy ezt a technológiát egy marógéppel együttesen alkalmazva hibrid gyártás is megvalósítható, ezzel gyorsítva a posztprocesszálást. A DMLS-el összehasonlítva ezzel az eljárással sokkal gyorsabb nyomtatási sebességet érhetünk el, de a por nem tökéletes szóródása miatt nem is kapunk olyan finom felületet. 


\subsection{Prototípus készités}

Egy alkatrész fejlesztése nem történhet csupán elméleti síkon. A legyártott alkatrésznek mindig lehetnek gyártási hibái, de az is felmerülhet, hogy maga a kész konstrukció nem megfelelő. Az ilyen későn észlelt hibák előzetes felfedezésére szolgál a prototípus készítés (angolul: prototyping). Ez egyfajta fejlesztési, tesztelési és tervezési módszer, amivel mielőtt kiadnánk a kész termékünket, egy fizikailag elvégzett vizsgálattal rájöhetünk mivel finomíthatjuk és fejleszthetjük a terméket és háríthatunk el esetleges közben megjelenő hibákat, problémákat. Ezt újra meg újra megismételjük, amíg nem tudjuk, hogy valóban müködik a termék és a fogyasztói igényeknek is eleget tesz. Ezeket a prototípusokat kis darabszámban kell legyártani, a lehető leggyorsabban. Ehhez nagyon jó eszközként tud szolgálni a 3D nyomtatás. Tervezési paradoxonnak hívják azt a jelenséget, amikor a termék még nagyon kezdetleges fázisban van és a tervezőmérnöknek kevés tudása van róla, valamint annál is kevesebb tapasztalata a viselkedéséről és igényekről (2. ábra).

2. ábra: Tervezési paradoxon

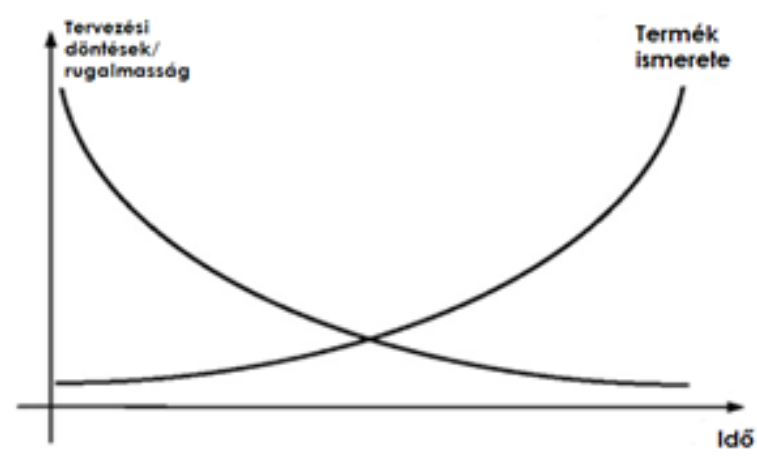

Forrás: Kuang-Hua Chang: Product performance evaluation using CAD/CAE, 2013

Ez egy súlyos probléma, hiszen a termékkel kapcsolatos legfontosabb döntések mindig a tervezési fázis legelején merülnek fel, ezzel kevésbé rugalmassá téve később a konstrukciót. Nem a digitálisan megtervezett kész terméket teszteljük, hanem már a tervezési lépcsőkön lépdelve, a különböző verziókat is. Ezzel szélesebb képet kaphatunk, hogy melyek azok az irányok, amelyek a hatékonyabb darab felé mutatnak. Persze nem minden egyes kis milliméternyi változás után kell azonnal egy prototípust gyártani, de egy adott fok után már érdemes. Ez a módszer egy olcsó, alacsony kockázatú gyártási módot segít megvalósítani úgy, hogy minél hamarabb próbálja a legtöbb tudást átadni a tervezőnek a termékről, mielőtt annak tényleges gyártását elkezdjük. Időt és pénzt takarít meg az újítóknak és az érdekelt feleknek tehát valaminek csak a legjobb változata jöhet létre. (Chang, 2013) 


\subsection{Hibrid megoldások}

Ahogy a gyártási trend a testre szabás és a személyre szabás felé halad, az egyedi és pótalkatrész-ellátás egyre kritikusabb üzleti kihívássá válik. Figyelembe véve a hagyományos ellátó láncokat és logisztikai megoldásokat, vannak olyan idő és hely kritikus szituációk, amikre ez a hagyományos utánpótlás nem elég gyors. Egy hajó esetén például az óceán közepén, a legközelebbi szerviz lehetőségtől több száz, esetleg ezer kilométerre nem opció, hogy megvárja az utánpótlást, hanem magával kell vinnie a csere alkatrészeket. Ez mind értékes helyet foglal a raktérben, ezért a hibrid gyártás használata esetén, a helyben legyártott alkatrész sokkal praktikusabb lehetőségeket biztosít. A sok pótalkatrész helyett csak a gép és az alapanyag foglal helyet. Ezt a fajta utánpótlást már a Nemzetközi Ürállomáson is bevezették 2014-ben (NASA, 2014).

3. ábra: Hibrid gyártási folyamat előgyártmánnyal indulva

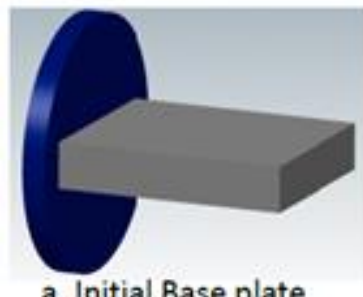

a. Initial Base plate

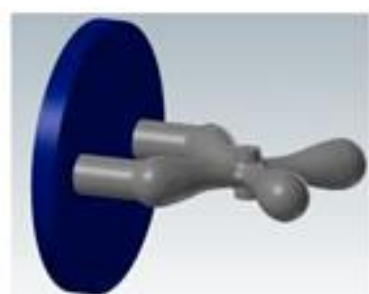

d. Step 1 Finishing operation

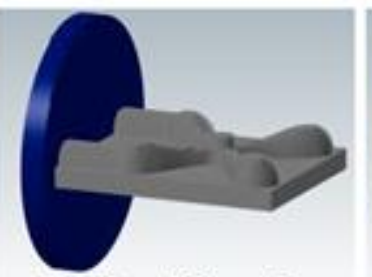

b. Step 1 Roughing from top

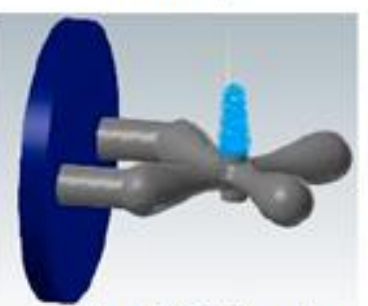

e. Step 2 AM from top

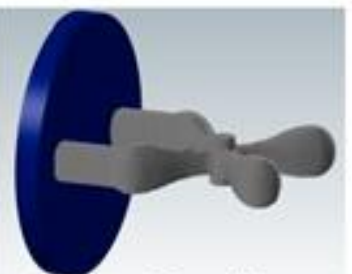

c. Step 1 Roughing from bottom

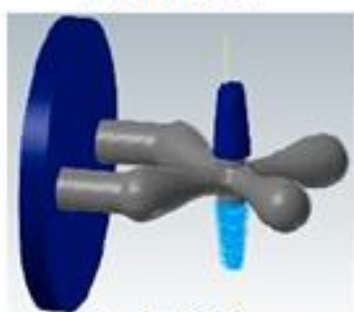

f. Step 2 AM from bottom

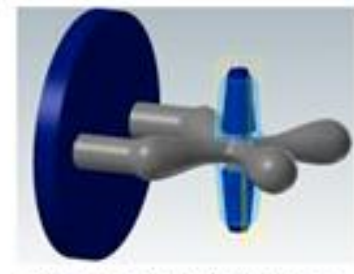

g. Step 3 Final finishing

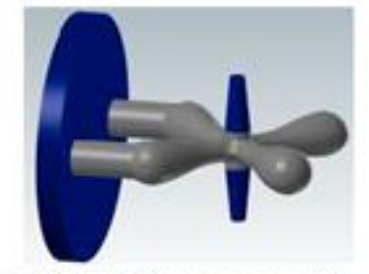

h. Step 3 Final geometry

Forrás: Niechen Chen, Mattlew Frank: Process planning for híbrid additive and subtractive manufacturing to integrate machining and directed energy deposition ,2019 
Általában a fémgyártásban az alapanyag tömegre vonatkoztatva az additív technológia sokkal drágább, mint a szubtraktív technológiában használatos előgyártmányok és a feldolgozási idő is hosszabb. A hibrid additív és szubtraktív gyártási folyamatok esetén a szubtraktív rész általában a gyártási folyamat utólagos megmunkálására szolgál a jobb felületi minőség eléréséhez, ami kritikus szempont, ha hibrid gyártási folyamatról beszélünk. Azonban, ha a két technológiát úgy integráljuk, hogy mindkettő erősségére építünk, egy még hatékonyabb gyártást érhetünk el. Ahelyett, hogy az additív technológiát használjuk a teljes forma felépítésére, még gazdaságosabb megközelítés lehet először egy kisebb előgyártmányból forgácsolni és közelíteni az alapformát. A részben elkészített geometria valójában egy alapként fog müködni az additív folyamat számára. Ehhez additív módon hozzáadni a hiányzó vagy túlnyúló részeket kevesebb idő lenne. A 3. ábrán látható egy ilyen gyártási folyamat CAM terve. Ebben az értelemben mindkettő gyártástechnológia sokkal hatékonyabb kiaknázható kisebb költséggel és gyorsabb gyártási sebességgel.

\section{5. Összehasonlítás módjai}

Az összehasonlítást a gyártás és a munkadarab paraméterei alapján végezzük. Egyes paraméterek esetén figyelembe kell vennünk azt is, hogy az additív gyártásnál csak két különböző technológiát vizsgáltunk (ezek a leggyakoribbak a fémnyomatás esetén). Továbbá fontos megjegyezni, hogy általánosságban tárgyaljuk a gyártási folyamatokat, így lehetnek egyes esetek és különleges munkadarabok, ahol ez az összehasonlítási mód nem megfelelő vagy érvényét veszíti. A vizsgált paraméterek a következők:

- felületi minőség

- gyártási idő

- gyártási költség

- gyárthatóság

- anyag

- anyagveszteség

- poszt processzálás szükségessége

- alkatrész tömeg

- anyag és gép költség

- darabszám 


\section{Eredmények}

\subsection{Felületi minőség}

A felületi érdesség nagyon fontos eleme egy alkatrésznek, mivel ha a darab felületének el kell tudnia csúszni egy másik felületen, akkor jobb minőség szükséges. Az illeszkedő felületek esetén ezért szigorú alak és mérettürésekkel kell gyártanunk. Persze ennek is megvan a maga határa, hiszen minél jobb a felületi minőség, annál nagyobb a megmunkálási költség is. Marás esetén normál gyártási feltételek esetén Ra3,2 és Ra0,8 közötti értékeket érhetünk el, de különlegesebb feltételek esetén, mint sủrübb szerszámpálya vagy egy a célnak legmegfelelőbb szerszám használatával ez a tartomány elérheti az Ra0,4 - Ra0,2-es szintet is.

Poros nyomtatás esetén a porszemcsék nagysága nagyban befolyásolja a végső felület milyenségét, valamint a rétegek vastagságát is. Az itt megjelenő gyártási pontatlanságok a nem egyenletes por elhelyezkedése (hullámosság az ágyban) vagy a tárgyasztal süllyedésének a mértéke nem elég pontos. Az ágy felszínének már tárgyalt hullámosságát és durvaságát gyártás közbeni vizsgálattal lehet kompenzálni. A lézer erejének csökkentésével is el tudunk érni finomabb felületet, de ilyenkor esélyes a kifáradási határ csökkenése az anyagban. Ezzel a technológiával az elérhető felületi érdesség értéke 10 és 20 m közötti tartományban található, de különleges gyártási feltételek és anyagok esetén ez a szám lecsökkenhet akár Ra5-re is. (Sanaei, Fatemi, 2020) LDT esetén a por a fúvókából nem tud tökéletesem áramlani, ezáltal kisebb területen a lézer környezetében szétszóródik és durva felületet eredményez. Továbbá figyelni kell a kiáramló anyag mennyiségéhez mért állandó szerszám sebességet, ezzel biztosítva, hogy mindenhol megfelelő magasságú a rétegünk. Ha kicsit is lassabban halad a fúvóka, akkor vastagabb, ha gyorsabban, akkor pedig vékonyabb réteg kerül a darabra. Ezeknek a hibáknak a kiküszöbölésére alkalmazott az a módszer is, hogy minden rétegen elhelyezkedik egy kijelölt pont, amin mindenképp át kell haladnia a munkapontnak és az adott réteg kerületéből számolva meg adható az út. Innentől már csak a vezérlésnek a geometria lekövetése mellett azt kell figyelni, hogy az általa megadott konstans sebességgel ténylegesen annyi idő alatt tér- e vissza a kijelölt ponthoz, mint amennyi alatt kellett volna. A legmodernebb gépeknél ezt már egy tanuló mesterséges intelligenciával oldják meg, ami folyamatosan figyeli és korrigál, hogy ne jöjjön létre pontatlan geometria lekövetés, valamint mérethiba. Ezzel a gyártásmóddal hasonló felületi érdességet tudunk elérni, mint a homoköntött alkatrészek esetén, ami normál feltételek esetén Ra12,5. 


\subsection{Gyártási idö}

A gyártási sebességet tekintve a forgácsolás gyorsabb, mint a nyomtatás, mivel itt a nagyolás, elősimítás és simítás különböző sebességekkel történik, különösen akkor, ha alkalmazzuk azt az elvet, miszerint a lehető legtöbb anyagleválasztást 3 tengelyes üzemmódban végezzük. Nyomtatás esetén állandónak mondható sebességet tudunk elérni. A porágyas nyomtatásnál a szelvény nagysága tudja még dinamikusan változtatni a gyártás sebességét. Ha másik anyaggal szeretnénk nyomtatni, akkor teljes mértékben ki kell tisztítani a munkateret, és a poradagoló szerkezetet is ki kell cserélni, ami a 2 órás csereidőtől másfél napig is terjedhet géptípustól függően. Ennél sokkalta gyorsabb, de még nem éri el a forgácsolás sebességét az LDT típusú nyomtatás.

\subsection{Gyártási költség}

A támaszték mellőzése nem csak anyagköltség csökkentést eredményez, hanem a gyártási idő csökkenését is, hiszen nem kell az elejétől fogva építenünk valamit, amit a kész alkatrészen nem is fogunk használni. Ráadásul még utómunkálatokkal el is kell távolítani a támasztékokat, ami megint csak növeli a gyártási időt. Éppen ebből az okból kell vizsgálni a legyártandó darab milyenségét. Ha nincs szükség nagyon finom felületre, akkor az LDT a jobbik választás ilyen téren. Ennek ellenére egyes esetekben (például orvosi darabok esetén) szükséges a finom felület, amiket nem feltétlen tudunk utólag megmunkálni, ezért vállalni kell a technológiából adódó hosszabb gyártási időt a kisebb rétegvastagságokkal (és ha szükséges, támasztékokkal) például a lézeres technológiával. A drága alapanyag is meglehetősen nagy részét teszi ki a költségeknek, mivel a porral nyomtatás még nem eléggé elterjedt. Később várható mind az alapanyagok, mind a gépek árának csökkenése, ha új módszerek és előállítási procedúrák jelennek meg vagy a jelenlegiek lesznek hatékonyabbak és sokkal olcsóbb az előállításuk. Ezzel szemben a forgácsolásnál olcsóbb az alapanyag, de a forgácsból már nem készül munkadarab, így nagyobb arányban ontja magából a hulladákot a gyártás. Ez a fajta veszteség nem jelentkezik jelentősen inkább az emulzióban áztatott forgács megfelelő kezelése, tárolása, szállítása és maga az emulzió, ami még a szerszám és a géphasználati költségek mellett megjelenik hosszútávon.

\subsection{Gyárthatóság}

A szabad felületek megmunkálása nem jelent gondot a szimultán 5 tengelyes forgácsoló gépeknek egészen addig, amíg olyan felületet kell megmunkálni, ahol vékony fal van. Már az egyszerübb 3 tengelyes munkadaraboknál is komoly akadályt jelent a vékony zsebfalak 
gyártása, mivel itt kisebb paraméterekkel kell az anyagot leválasztani (kisebb fogásvétel és előtolás) és ezeknek is van egy minimum falvastagsága, amit lehet gyártani. Ezeknek a paramétereknek csökkentése és a falvastagság az anyagminőségtől is függ, de mindenképpen növeli a ciklusidőt. Nyomtatás esetén is van megkötés a minimum falvastagságra, de ez nem szerszám és gyártásból adódó kérdés, hanem szerkezeti. A vastagság egy fal esetén például a fal függőleges kiterjedésétől függ. Egy $5 \mathrm{~mm} 2$-es falat például minimum $0.3 \mathrm{~mm}$ vastagra kell nyomtatni, de egy $100 \mathrm{~mm} 2$ területü fal esetén már $1 \mathrm{~mm}$. (Fabian, 2018) Továbbá, a fal szerkezeti elhelyezkedése és felszíne is számít. Lehet szó támasztott falról vagy dombornyomott falról, ezek a tulajdonságok szintén befolyásolják a használható minimum vastagságot. Az összetett (komplex) felületek belső oldalának kialakíthatóságát nagyban befolyásolja, hogy a szerszám mennyire fér oda a felülethez, ami igaz a külső felületek hozzáférhetőségére is, de legnagyobb kihívást a belső részek jelenthetik. Ilyen szempontból a nyomtatás rétegről rétegre haladásával könnyü dolgunk van. Technológiai hátrány a poros nyomtatásnál, hogy nem tudjuk a darabot gyártás közben mozgatni, így csak egy irányú rétegépítés érhető el, ami esetében a mechanikai igénybevételeket is figyelembe kellhet venni egy alkatrész tervezése során. Az LDT technológiával ilyen szintü megkötés nincs, sőt elérhetőek már olyan gépek, ahol a szerszám szabadon mozog a darab körül 6 szabadsági fokkal (általában robot karok) és ezzel nincs az egész alkatrészre vonatkozó fix réteg orientáció, hanem a különböző alrészeket (például egy elágazás esetén) úgy gyártják, hogy azokon már az alaptól eltérő szögben álló rétegeket helyeznek el, ezzel változó az építési irány. Ennek hátránya, hogy az anyag deformálódhat a túlnyúló részeken, ha nincs támaszték építve a darabbal együtt (ez leginkább a mủanyaggal való gyártáskor jelenik meg komolyabban, de mivel a legkisebb ilyen nem megfelelö belső feszültség egy kritikus helyen hibás munkadarabot eredményezhet). Támaszték gyártása megoldható, de csak nehezítené a geometriát és az anyagtöbblet mellett a gyártási idő is növekedne a korlátozott hozzáférhetőség mellett.

\subsection{Anyag}

Az additív gyártás alapanyagai magasabbak, mint a hagyományos forgácsoló megmunkálások esetén. A porfémek ára nagyjából nyolcszor drágább, mint az ezeknek megfelelő előgyártmányok ára. A pontos költség függ több tényezőtől is, mint az additív technológia és a különböző felhasznált anyagok aránya. A magas alapanyag árát a nyersanyagfelhasználás ellensúlyozza, mivel egy kevésbé komplex darab esetén sokkal hatékonyabb az anyagfelhasználás (nincs támaszték), ezzel megközelítőleg a 18-30\%-os tartományba esik a gyártási költség is. 


\subsection{Anyagveszteség}

Anyagveszteség szempontjából érthető módon a nyomtatás a hatékonyabb, bár később tárgyaljuk, az alapanyagok árának relációjával láthatjuk azt is, ami alapján ez az reláció meg is fordulhat. Ennek ellenére mennyiségét tekintve a nyomtatás termel kevesebb hulladékot, ami nem elhanyagolandó az egyre szigorodó környezetvédelmi eröírások mellett. Forgácsolás esetén mivel a technológia alapja, hogy leválasszuk az anyagot, így jóval nagyobb hulladéktermelése van. Forgácsolás esetén a maximális anyagleválasztás mértéke körülbelül $30 \%$. Egyedi gyártásnál a profit nagysága miatt ez a szám lehet akár $70 \%$ is, de ez sorozatgyártásnál már nem hoz hasznot. Így két esetet kell megkülönböztetnünk, a nagy vagy közepes sorozatot és a kis sorozat gyártását. A darabszám befolyását később tárgyaljuk, de anyagleválasztással kapcsolatban mindenképp elmondható, hogy minél több anyagot választunk le, annál több a gépi és szerszámköltség a kopás miatt, így megfontolandó még a kis sorozatnál is, hogy a 30\% átlépése mennyire hasznos.

\subsection{Poszt processzálás szükségessége}

Lehetséges, hogy a darabunkhoz nincs szükség utólagos megmunkálásra, de forgácsolás esetén ez csak hőkezelés vagy bevonatolás formájában jelenik meg (figyelembe nem véve a hibás gyártást). Nyomtatás esetén, ha nem tudunk elég sima felületeket nyomtatni az gyártási idő szüke vagy a technológiai határok miatt, akkor szükséges a csatlakozó, felfekvő vagy illeszkedő felületeket megmunkálni (itt jelenik meg a hibrid gyártás egyik előnye, hogy egy gépben elvégezhető a két müvelet). Tehát összességében elmondható, hogy a nyomtatás után szükség van az utólagos megmunkálásra valamilyen mértékben.

\subsection{Alkatrész tömege}

Manapság a könnyüsúlyú konstrukciók készítése az egyik legfontosabb technológia kihívás, ahol a fö cél, hogy javítsuk az energiafelhasználást és a gépek teljesítményét (lásd jármüipar). Egyik nagyon fontos tulajdonság a fajlagos modulus, amely egy olyan anyagtulajdonság, amely az anyag tömegsürüségére eső rugalmassági modulusából áll. Merevség és tömegarány vagy fajlagos merevség néven is ismert. A magas fajlagos modulusú anyagok széles körben alkalmazhatók az üripari vagy jármüipari alkalmazásokban, ahol minimális szerkezeti súlyra van szükség. Ez az érték a Young-modulus és a sürüség arányával számolandó. Tehát ha súlykritikus az alkatrész, a nyomtatás segítségével már nem csak az anyagot spórolhatunk, hanem a darab kitöltésének százalékával is módosítható, hogy könnyebb, de mégse gyengébb darabot kapjunk. A kitöltési minták is változtathatók, ezzel a különböző igénybevételek ellen erősítve az alkatrészt (Ficzere \& Lukács, 2020.). A szabadon választható anyagösszetétel és a 
megfelelő kialakítású és sürüségü kitöltéssel képesek lehetünk olyan erős darabot nyomtatni, mintha egy tömör forgácsolt darab lenne.

\subsection{Anyag és gépi költség}

Forgácsoláshoz beszerezni az alapanyagot jelentősen olcsóbb a nyomtatáshoz képest, de sajnos, mint már tárgyaltuk, nem tudunk bármilyen anyagot feltétlenül marni, mivel ez függ a gép teljesítményétől, a szerszám anyagától és az anyag alakíthatóságától is. Nyomtatás esetén a nagyobb költség az alapanyagot jelenti, mivel itt por formájában kell felhasználni az anyagot, ami emeli a gyártási költségeket. Ennek ellenére lehetnek olyan esetek, amikor ezt a módszert érdemesebb használni, mivel a pornak köszönhetően mechanikai ötvözést tudunk végrehajtani és ezzel olyan erős anyagokkal tudunk dolgozni, ami forgácsolás esetén drága és különleges szerszámokat igényelne. Továbbá annak ellenére, hogy drágább az alapanyag, kevesebb hulladék termelődik, így a beszerzett/felhasznált anyag aránya igen jónak mondható az újrahasznosítás jegyében. (Krishna, Srikanth, 2019) A gyártás során figyelembe kell venni a gépek árait is. Egy alapfelszereltségü 5 tengelyes maró megközelítőleg 38 millió forint, és ez még nem tartalmazza a szerszámkészlet árát, ami a speciális kialakítású szerszámok miatt 1-2 millió forintban biztosan hozzáadódnak a költséghez. Ennek az árát kell a profitból visszahozni, valamint magának a gépnek a fenntartása és üzemeltetése is egyéb költségekkel jár, ami különlegesebb gépeknél szintén növekvő tendenciát mutat. A gépi költség mellett a szakértelem is igen fontos, hogy legyen ki kezelje ezeket a gépeket, megtervezze a gyártást. Ennek a szakértelemnek a megfizetése nagyjából azonos lehet additív és szubtraktív oldalon, bár inkább a nyomtatási szaktudás jelenleg drágább lehet, mivel még egy kevésbé általános területről beszélünk. Fontos megjegyezni, hogy az 5-tengelyes marási müveletek a CAM rendszerekben csak korlátozott beállítási lehetőséget biztosítanak a szerszámpályák létrehozásához, azaz az 5 tengelyes marási müveletek könnyen kezelhetők, de az „elökészítettségük” miatt nem biztosítanak teljes felügyeletet a szerszámpályák felett. Éppen ezért a forgácsolással foglalkozó szakemberek tudása is elvárt magasabb szinten, ezzel növelve az értéküket.

\subsection{Darabszám}

A darabszám a szériagyártás esetén fontos, mivel technológiából adódóan a forgácsolás közép és nagysorozat gyártása esetén profitáló. A közép sorozatot megközelítőleg 1000 darabtól kell tekinteni. Ennél a darabszámnál már egyre kevésbé csökken az egy darabra jutó költség. Porágyas nyomtatás esetén, ha elég nagy a munkatér, egy ciklusban több alkatrészt is lehet nyomtatni egyszerre. Ezzel csökkenthető a csereidő a ciklusok között és a gépi költségek is csökkenthetők. Ha a munkatér nem elég nagy több alkatrész egyidejü nyomtatásához, akkor 
csak a kis sorozatú gyártás a kedvezőbb. Növekvő darabszám esetén nem csökken jelentősen az egy darabra jutó költség. Fúvókás nyomtatás esetén több darab gyártása nem jellemző, ezért a csereidő jelentősen jelen van. Ez esetben is elmondható, hogy a mennyiséggel minimálisan csökken csak az egy darabra jutó költség.

\section{Következtetés}

A felsorolt paraméterekkel való összehasonlításkor látható, hogy nem mindig lehet konkrét határt húzni vagy a legjobbat választani. Egy termék gyártása esetén nagyon sokat számít, hogy a paramétereket milyen fontossággal vesszük figyelembe. Ha felállítjuk a különböző jellemzők fontossági sorrendjét és megfigyeljük, hogy az adott jellemző esetén melyik a legjobb választás, a vizsgálat végére kiadódhat, hogy összességében melyik technológiának tudjuk a legtöbb erősségét kihasználni. Ez darabonként mindig más, éppen ezért nagyon nehéz leírni egy ilyen dinamikusan változó, mindent összefogó modellt. A kiválasztott 10 paraméter csak egy kisebb része azon jellemzők csoportjának, amit hozzáadva a vizsgálathoz, sokkal bonyolultabb vizsgálatot, de talán pontosabb döntést eredményezne. Továbbá, a konkrét számadatok és kalkulációk segítségével is növelhető a pontosság, de ez a döntési procedúrát is bonyolultabbá és nehézkessé teszi. 
1. táblázat: A három tárgyalt technológia összehasonlító táblázata

\begin{tabular}{|c|c|c|c|}
\hline Összehasonlítás & 5 tengelyes marás & DMLS & $L D T$ \\
\hline Felületi minőség & $R a 3,2-R a 0,2$ & $R a 20-R a 5$ & $R a 12,5$ \\
\hline Gyártási idö & relatív gyors & lassú & $\begin{array}{l}\text { gyorsabb, mint a } \\
\text { porágyas nyomtatás }\end{array}$ \\
\hline Gyártási költség & alacsonyabb & magas & magas \\
\hline Gyárthatóság & $\begin{array}{l}\text { limitált geometria, } \\
\text { szerszám helyzet } \\
\text { korlátolt }\end{array}$ & bármilyen forma & bármilyen forma \\
\hline Anyag & $\begin{array}{l}\text { olcsóbb, } \\
\text { korlátozottabb }\end{array}$ & $\begin{array}{l}8 x \text { drágább, } \\
\text { szabadabb } \\
\text { mechanikai ötvözés }\end{array}$ & $\begin{array}{l}8 x \text { drágább, } \\
\text { szabadabb } \\
\text { mechanikai ötvözés }\end{array}$ \\
\hline Anyagveszteség & $\begin{array}{l}\text { elögyártmány-kész } \\
\text { darab térfogata }\end{array}$ & $\begin{array}{l}\text { támaszték, simitással } \\
\text { leválasztott }\end{array}$ & $\begin{array}{l}\text { támaszték, simitással } \\
\text { leválasztott }\end{array}$ \\
\hline $\begin{array}{l}\text { Poszt processzálás } \\
\text { szükségessége }\end{array}$ & opcionális hőkezelés & $\begin{array}{l}\text { felületi minöség } \\
\text { javitása, támaszték } \\
\text { eltávolitása }\end{array}$ & $\begin{array}{l}\text { felületi minöség } \\
\text { javitása, támaszték } \\
\text { eltávolitása }\end{array}$ \\
\hline Alkatrész tömege & $\begin{array}{l}\text { anyagminöségtöl } \\
\text { függ }\end{array}$ & $\begin{array}{l}\text { anyagminöségtöl és } \\
\text { kitöltés mértékétől } \\
\text { függ }\end{array}$ & $\begin{array}{l}\text { anyagminöségtöl és } \\
\text { kitöltés mértékétőll } \\
\text { függ }\end{array}$ \\
\hline $\begin{array}{l}\text { Anyag és gépi } \\
\text { költség }\end{array}$ & $\begin{array}{l}\text { olcsóbb anyag, } \\
\text { olcsóbb gép, magas } \\
\text { szakértelem }\end{array}$ & $\begin{array}{l}\text { drágább anyag, } \\
\text { drágább gép, magas } \\
\text { szakértelem }\end{array}$ & $\begin{array}{l}\text { drágább anyag, } \\
\text { drágább gép, magas } \\
\text { szakértelem }\end{array}$ \\
\hline Darabszám & $\begin{array}{l}\text { közepes- és } \\
\text { nagysorozathoz } \\
\text { profitáló }\end{array}$ & $\begin{array}{l}\text { alig csökkenö } \\
\text { termékár, kis } \\
\text { sorozathoz }\end{array}$ & $\begin{array}{l}\text { alig csökkenö } \\
\text { termékár, kis } \\
\text { sorozathoz }\end{array}$ \\
\hline
\end{tabular}

Forrás: saját elemzés

\section{5. Összefoglalás}

Az összehasonlítás eredményéből létrehozott 1.táblázaton is látható, hogy az additív és a szubtraktív gyártástechnológiák között nem lehet megítélni melyik a hatékonyabb vagy jobb. Ezen verseny nyertesének megválasztása helyett sokkalta fontosabb, hogy a lehető legjobban ismerjük az általunk használt technológiákat. Ezzel a tudással karöltve lehetőség van ötvözni a kettőt és kiaknázni a hibrid technológia eddig kevésbé ismert erősségeit. Az idő múlásával ezek a rendszerek és módszerek egyre elterjedtebbek lesznek és jobb hatékonyságot fognak elérni a kutatások és fejlesztéseknek köszönhetően. Mondhatni, a nyomtatás még nem vált általánossá kellő mértékben az iparban, egyeseknek ez a technológia még ma is újszerünek hathat. További célunk, hogy az egyes alkatrészek esetén különböző súlyszámok hozzárendelésével valós értékekkel tudjunk számolni és ezzel egy megközelítő becsült értéket kapni. 


\section{FELHASZNÁLT IRODALOM}

1. Andreas Gebhardt: Understanding Additive Manufacturing. Hanser Publishers, Munich, 2011, p 71.

2. Fabian: How to Choose the Perfect Wall Thickness for 3D Printing https://i.materialise.com/blog/en/how-to-get-the-perfect-wall-thickness-when-turningyour-3d-model-into-a-3d-print/ (Letöltve: 2021 január 13.)

3. Ficzere Peter, Borbas Lajos, Szebenyi Gabor, Reduction possibility of residual stresses from additive manufacturing by photostress method, Materials Today: Proceedings, Volume 4, Issue 5, Part 1, 2017, Pages 5797-5802, ISSN 2214-7853, https://doi.org/10.1016/j.matpr.2017.06.048.

4. Ficzere Péter, Effect of 3D printing direction on manufacturing costs of automotive parts, International Journal for Traffic and Transport Engineering $11: 1$ pp. 94-101. (2021), DOI: 10.7708/ijtte.2021.11(1).05

5. Ficzere, Péter; Lukács, Norbert, examination of possibilities of the strength modification in the case of fdm/fff manufacturing technology, Design of Machines and Structures $10: 2$ pp. 27-34. , 8 p. (2020), Doi: 10.32972/dms.2020.010

6. Formlabs: Minimum wall thickness for 3D printing https://i.materialise.com/blog/en/how-to-get-the-perfect-wall-thickness-when-turningyour-3d-model-into-a-3d-print/ (Letöltve: 2021 január 26.)

7. Györi Márk, Ficzere Péter,_Use of Sections in the Engineering Practice,_Periodica Polytechnica Transportation Engineering, 45(1), pp. 21-24. (2017) https://doi.org/10.3311/PPtr.9144

8. L. Siva Rama Krishna, P.J. Srikanth: Evaluation of environmental impact of additive and subtractive manufacturing processes for sustainable manufacturing, Materials Today: Proceedings, 2021, ISSN 2214-7853, https://doi.org/10.1016/j.matpr.2020.12.060

9. NASA: Space Tools On Demand: 3D printing in Zero G https://www.nasa.gov/sites/default/files/files/3D_Printing-v3.pdf (Letöltve: 2021. január 3.)

10. Niechen Chen, Matthew Frank: Process planning for hybrid additive and subtractive manufacturing to integrate machining and directed energy deposition, Procedia Manufacturing, Volume 34, 2019, Pages 205-213, ISSN 2351-9789, https://doi.org/10.1016/j.promfg.2019.06.140

11. Niloofar Sanaei, Ali Fatemi: Analysis of the effect of surface roughness on fatigue performance of powder bed fusion additive manufactured metals, Theoretical and Applied Fracture Mechanics, Volume 108, 2020, 102638, ISSN 0167-8442, https://doi.org/10.1016/j.tafmec.2020.102638

12. Prahar M. Bhatt, Rishi K. Malhan, Pradeep Rajendran, Satyandra K. Gupta: Building free-form thin shell parts using supportless extrusion-based additive manufacturing (2019) https://doi.org/10.1016/j.addma.2019.101003 